Military Technical College Kobry El-Kobbah, Cairo, Egypt.

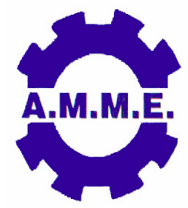

$15^{\text {th }}$ International Conference on Applied Mechanics and Mechanical Engineering.

\title{
REQUIREMENTS OF ISO/TS 16949:2009 FOR AUTOMOTIVE- RELATED PRODUCTS AND CASE STUDY FOR ITS APPLICATION
}

\author{
M.M. El-Dessouky \\ Prof. Dr., Chem. Engineering Dept., MTC.
}

\begin{abstract}
Organizations of automotive-related products are concerned with achieving improvement in their performance by controlling their activities, products and services. The International Standard ISO/TS 16949:2009 provides well the requirements of management system elements to enable an organization to develop and implement its policy, objectives and processes considering legal requirements to provide high quality and safe products. The effectiveness and success of the system depends on commitment of all levels and functions of the organization, especially top management. The aim of this International Standard is to support establishing, implementing and improving management system and to assure interested parties that an appropriate and safe spare parts for automotive industry will be produced according the required specifications.
\end{abstract}

After offering the requirements of the main management system elements, case study for automotive-related industry will be discussed how to establish, implement and improve effective system. 